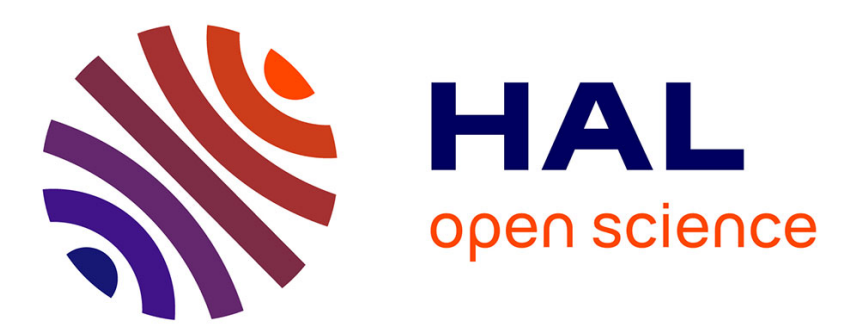

\title{
Magnetic Properties of SrO.nFe2O3 Powder Synthesized by Self-Combustion Process
}

\author{
E. Otsuki, H. Matsuzawa
}

\section{To cite this version:}

E. Otsuki, H. Matsuzawa. Magnetic Properties of SrO.nFe2O3 Powder Synthesized by SelfCombustion Process. Journal de Physique IV Proceedings, 1997, 07 (C1), pp.C1-323-C1-324. 10.1051/jp4:19971128 . jpa-00254770

\section{HAL Id: jpa-00254770 https://hal.science/jpa-00254770}

Submitted on 1 Jan 1997

HAL is a multi-disciplinary open access archive for the deposit and dissemination of scientific research documents, whether they are published or not. The documents may come from teaching and research institutions in France or abroad, or from public or private research centers.
L'archive ouverte pluridisciplinaire HAL, est destinée au dépôt et à la diffusion de documents scientifiques de niveau recherche, publiés ou non, émanant des établissements d'enseignement et de recherche français ou étrangers, des laboratoires publics ou privés. 


\title{
Magnetic Properties of $\mathrm{SrO} \cdot \mathrm{nFe}_{2} \mathrm{O}_{3}$ Powder Synthesized by Self-Combustion Process
}

\author{
E. Otsuki and H. Matsuzawa
}

Materials Development Laboratory, Tokin Corp., 6-7-1 Koriyama, Taihaku-ku, Sendai 982, Japan

\begin{abstract}
SrO} \cdot n \mathrm{ne}_{2} \mathrm{O}_{3}(\mathrm{n}=1 \sim 6)$ powders were attempted to be synthesized by glycine nitrate process, and their crystal structure and magnetic properties were investigated. The powders prepared in a beaker were mixtures of $\alpha-\mathrm{Fe} 2 \mathrm{O}$ and $\mathrm{Sr}\left(\mathrm{NO}_{3}\right)_{2}$, which could be transformed to $\mathrm{M}$-phase with the coercivity of $7 \mathrm{kOe}$ by heat-treatment. Spray roasting process can afford to produce $\mathrm{M}$-phase directly, which shows $\sigma(18)=56 \mathrm{emu} / \mathrm{g}, \mathrm{H} \omega=5.3 \mathrm{kOe}$. The difference of coercivity by the preparation procedures can be attributed to grain size.
\end{abstract}

\section{INTRODUCTION}

Since practically attainable coercivity for ferrites is relatively small in comparison with anisotropy field, many attempts have been done to enhance the coercivity by chemical and powder metallurgical methods.

We attempted to prepare the $\mathrm{SrO}_{n} \mathrm{nFe}_{2} \mathrm{O}_{3}(\mathrm{n}=1 \sim 6)$ powders with glycine nitrate process(1), that is, a self-combustion of metal-nitrate/glycine complex aqueous solution.

\section{EXPERIMENTAL}

<Synthesizing in a beaker> Iron nitrate enneahydrate, strontium nitrate and glycine were weighed into prescribed compositons and dissolved in distilled water. The molar ratio of glycine to the total content of metal nitrates was 0.8 .

The aqueous solution turned into red-brown gel as water vaporized almost completely, and then caught fire to become a solid foam.

$<$ Spray roasting $>$ Similar aqueous solution, of which the molar ratio of glycine to total content of nitrates was 1 , was sprayed into furnace heated at $850-1150^{\circ} \mathrm{C}$. Foam powders were obtained from the bottom of the furnace.

\section{RESULTS AND DISCUSSION}

$<$ Sythesizing in a beaker > Figure 1 shows the XRD patterns from the powders fired and heat-treated powders at $1200^{\circ} \mathrm{C}$ in the air. The phases comprizing the powders were identified as follows:

$$
\text { (as fired) (heat-treated at } 1200^{\circ} \mathrm{C} \text { ) }
$$

$\mathrm{n}=6 \quad \alpha-\mathrm{Fe}_{2} \mathrm{O}_{3}, \mathrm{Sr}\left(\mathrm{NO}_{3}\right)_{2} \rightarrow \mathrm{SrO}_{6} 6 \mathrm{Fe}_{2} \mathrm{O}_{3}(\mathrm{M})$

$\mathrm{n}=3 \quad \alpha-\mathrm{Fe}_{2} \mathrm{O}_{3}, \mathrm{Sr}\left(\mathrm{NO}_{3}\right)_{2} \rightarrow \mathrm{SrO} \cdot 6 \mathrm{Fe}_{2} \mathrm{O}_{3}, 7 \mathrm{SrO} \cdot 5 \mathrm{Fe}_{2} \mathrm{O}_{3}$

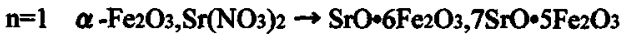

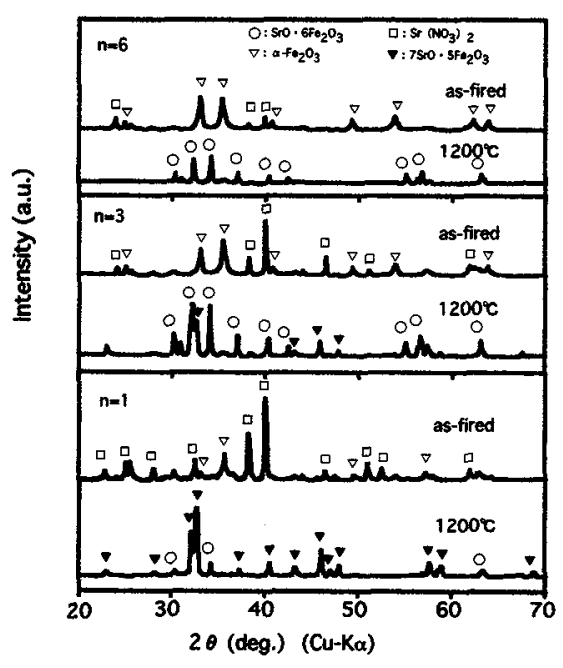

Fig.1 X-ray diffraction patterns of $\mathrm{SrO}_{-1 \mathrm{Fe}} \mathrm{O} 3$ synthesized in a beaker and heat treated at $1200^{\circ} \mathrm{C}$ for lhour 
High temperature heat-treatment up to $1200^{\circ} \mathrm{C}$ was necessary for the completion of reaction to ferrite.

Figure 2(a) and (b) show the magnetic properties of as fired and heat-treated powders. Saturation magnetization $\sigma(18)$ increases with an increase in n-value for the high temperature heat-treated samples. Coercivity $\mathrm{H}_{\mathrm{cJ}}$ increases gradually as $\mathrm{n}$ value increases and $\mathrm{H}_{\mathrm{c}}=7 \mathrm{kOe}$ was obtained with $800^{\circ} \mathrm{C}$ heattreated sample. However $\mathrm{HcJ}_{\mathrm{cJ}}$ decreases as heat-treatment temperature rises further.

The inability of M-phase synthesis in a beaker may be attributed to (1) too low temperature, (2) too short reaction time, (3) deficient in oxygen. Since M-phase can be obtained by heat-treatment of the fired powders, the direct synthesis of M-phase may be possible at high temperature reaction. Thus the spray roasting method was applied.

<sproy roasting > Figure 3 shows the XRD patterns from the powders spray roasted at $1000^{\circ} \mathrm{C}$. The sample with $n=6$ consists of almost single phase of $M$, and samples with $n=1,3$ contain $7 \mathrm{SrO} \cdot 5 \mathrm{Fe}_{2} \mathrm{O}_{3}$ as well.

Figure 4(a) and (b) show the magnetic properties of spray roasted powders. The dependence of $\sigma(18)$ on n-value is similar to beaker synthesized samples, however the effect of reaction temperature is not so much. In the case of $\mathrm{HcJ}$, its dependence on n-value differs each other for roasting temperature. Anyhow our experiment shows gradual change of $\mathrm{H}_{\mathrm{cJ}}$ with n-value for both preparation ways, and the sharp drop of $\mathrm{HcJ}$ at $n=3,4$ as reported by Kagotani(2) was not obtained.

Figure 5 shows the electron diffraction patterns for beakersynthesized powders followed heat-treatment at $800^{\circ} \mathrm{C}$ and $1200^{\circ} \mathrm{C}$. Reduction of $\mathrm{Hcs}_{\mathrm{cs}}$ by high temperature heat-treatment can be attributed to the grain growth.

\section{CONCLUSIONS}

The synthesis of Sr-ferrite was attempted by self-combustion of nitrate complex solution and the results are as follows: (1) By beaker synthesis and heat-treatment, $\mathrm{Sr}$-ferrite powders with $\mathrm{H}_{\omega}=7 \mathrm{kOe}$ and $\sigma(18)=17 \mathrm{emu} / \mathrm{g}(\mathrm{n}=6)$ were obtained.

(2) By spray roasting, Sr-ferrite powders with $\mathrm{H}_{\mathrm{cj}}=5.2 \mathrm{kOe}$ and $\sigma(18)=56 \mathrm{emu} / \mathrm{g}(\mathrm{n}=6)$ were obtained .

(3) Spray roasting can afford to produce the Sr-ferrite powders with higher magnetic properties by optimizing process conditions.

\section{ACKNOWLEDGMENTS}

The authors are grateful to Mr.T.Sato for TEM analysis.

\section{REFERENCES}

(1) L.A.Click etal.; Material Letters, vol.10,(1990),6.

(2) T.Kagotani etal.; IEEE Trans, on

Magn.,vol.31,No.6,(1995),3674.

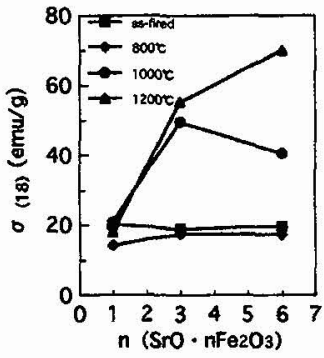

(a)

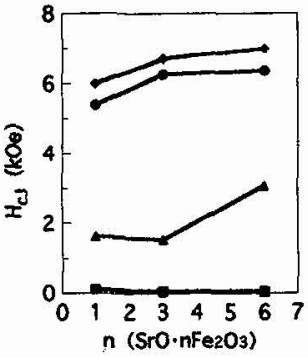

(b)
Fig.2 Magnetic properties of $\mathrm{SrO}_{0} \mathrm{nFe}_{2} \mathrm{O}_{3}$ synthesized in a beaker,before and after heat treatment.

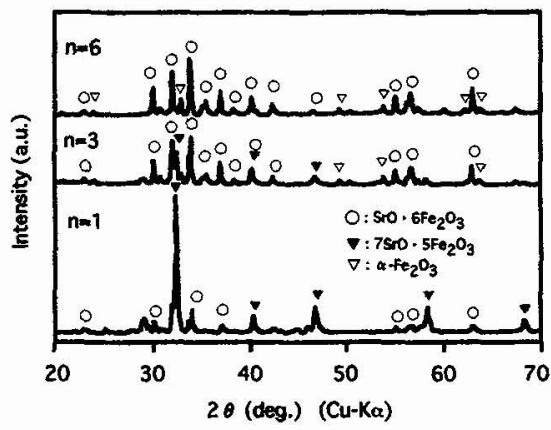

Fig.3 X-ray diffraction patterns of $\mathrm{SrO}^{-n \mathrm{nFe} 2 \mathrm{O} 3}$ spray roasted at $1000^{\circ} \mathrm{C}$

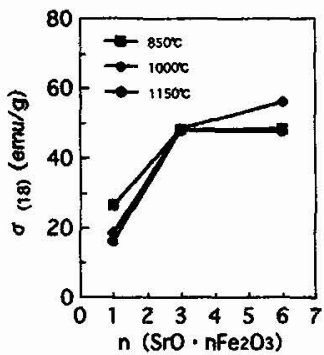

(a)

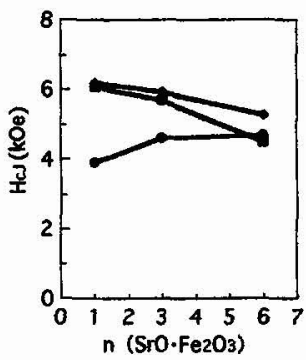

(b)
Fig.4 Magnetic properties of $\mathrm{SrO}_{n} \mathrm{nFe}_{2} \mathrm{O} 3$ spray roasted.

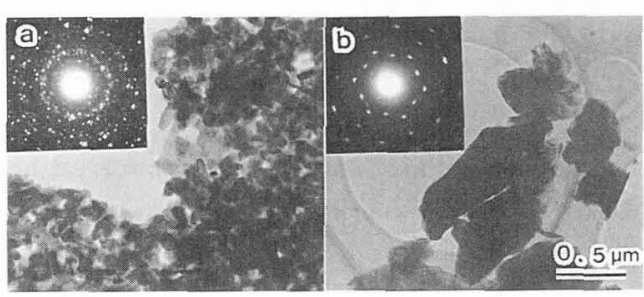

Fig.5 TEM of $\mathrm{SrO} \cdot 6 \mathrm{Fe} 2 \mathrm{O} 3$ synthesized in a beaker

(a) heat treated at $800^{\circ} \mathrm{C}$ for 1 hour

(b) heat treated at $1200^{\circ} \mathrm{C}$ for thour 